\title{
Pengaruh Metakognisi, Konsep Diri dan Kemandirian Belajar terhadap Kemampuan Pemecahan Masalah Matematika Siswa Kelas XI IPA SMAN 1 Gowa
}

\author{
Sukmawati \\ Prodi Matematika,UNISMUH, sukmawati@unismuh.ac.id \\ St. Nur Humairah Halim \\ Prodi Matematika,UNISMUH, irahumairah082@gmail.com \\ Nur Istianah \\ Mahasiswa Program Studi Matematika, UNISMUH, nuristianah0224@gmail.com
}

\begin{abstract}
ABSTRAK, Jenis penelitian ini adalah penelitian ex-post facto. Populasi dalam penelitian ini adalah seluruh siswa kelas XI IPA SMAN 1 Gowa sedangkan sampel dalam penelitian ini yaitu XI IPA 5 dan XI IPA 6 yang berjumlah 65 siswa. Teknik pengambilan sampel menggunakan cluster random sampling. Teknik pengumpulan data menggunakan angket dan tes. Teknik analisis data menggunakan analisis statistik deskriptif dan analisis statistik inferensial. Hasil penelitian ini menunjukkan bahwa (1) Secara parsial variabel metakognisi berpengaruh secara signifikan terhadap kemampuan pemecahan masalah matematika siswa kelas XI IPA SMAN 1 Gowa sebesar $81,2 \%$. (2) Secara parsial variabel konsep diri berpengaruh secara signifikan terhadap kemampuan pemecahan masalah matematika siswa kelas XI IPA SMAN 1 Gowa sebesar 89,6\%. (3) Secara parsial variabel kemandirian belajar berpengaruh secara signifikan terhadap kemampuan pemecahan masalah matematika siswa kelas XI IPA SMAN 1 Gowa sebesar 74,4\%. (4) Secara simultan variabel metakognisi, konsep diri dan kemandirian belajar berpengaruh secara signifikan terhadap kemampuan pemecahan masalah matematika siswa kelas XI IPA SMAN 1 Gowa dengan koefisien determinasi $\mathrm{R}^{2}=0,924$ yang berarti metakognisi, konsep diri dan kemandirian belajar memberi pengaruh sebesar 92,4\% terhadap kemampuan pemecahan masalah matematika siswa kelas XI IPA SMAN 1 Gowa dan sisanya sebesar 7,6\% dipengaruhi oleh faktor lain.
\end{abstract}

Kata Kunci: Metakognisi, Konsep Diri, Kemandirian Belajar dan Pemecahan Masalah Matematika

\section{PENDAhuluan}

Pendidikan merupakan suatu usaha atau kegiatan yang dijalankan dengan teratur dan terencana dengan maksud mengubah atau mengembangkan perilaku yang diinginkan guna mengembangkan diri anak didik sehingga mampu menghadapi setiap perubahan yang terjadi. Sekolah sebagai lembaga formal merupakan sarana dalam rangka tujuan pendidikan tersebut. Melalui sekolah, siswa belajar berbagai macam hal.
Sekolah merupakan lembaga pendidikan dan tempat berlangsungnya berbagai kegiatan, terutama kegiatan belajar mengajar yang tidak hanya melibatkan guru dan siswa, melainkan beberapa komponen lain yaitu kurikulum, sarana dan prasarana, lingkungan dan komponen lain yang saling mempengaruhi. Salah satu mata pelajaran yang menjadi dasar kurikulum wajib pada setiap sekolah ialah matematika.

Mata pelajaran matematika merupakan ilmu universal yang diajarkan dalam setiap jenjang pendidikan dan mendasari perkembangan teknologi modern, mempunyai peran penting dalam berbagai hal dan memajukan daya pikir manusia. Perkembangan pesat di bidang teknologi informasi dan komunikasi ini dilandasi oleh perkembangan matematika. Oleh karena itu matematika dijadikan sebagai mata pelajaran yang harus dipelajari siswa di setiap jenjang pendidikan, terutama pendidikan dasar dan menengah.

Berkaitan dengan proses pemecahan masalah matematika di sekolah, siswa dikatakan telah mampu belajar secara mandiri apabila telah mampu melakukan tugas belajar tanpa ketergantungan dengan orang lain. Ketidak bergantungan pada orang lain disebut sebagai sebuah kemandirian. Kemandirian dalam belajar dapat diartikan sebagai aktivitas belajar dan berlangsungnya lebih didorong oleh kemauan sendiri, pilihan sendiri dan tanggung jawab sendiri dari siswa. Menurut Hidayat (2009 : 2829) mengungkapkan bahwa dalam proses pembelajaran siswa tidak hanya menerima begitu saja apa yang diberikan guru melainkan harus mampu membangun hubungan dari konsep dan prinsip yang dipelajari, kondisi tersebut dapat memunculkan kemandirian belajar sehingga 
siswa mampu mengaktualisasi kebutuhankebutuhan sesuai dengan potensi yang dimilikinya. Siswa yang memiliki kemandirian belajar, tidak akan terus menerus tergantung pada materi yang diberikan oleh guru di kelas.

Hal ini disebabkan kebanyakan siswa menganggap bahwa setiap mata pelajaran relatif sulit, sehingga setiap tugas yang diberikan oleh guru tidak dikerjakan sendiri terlebih dahulu, tetapi kebanyakan dari mereka hanya mencontek pekerjaan dari temannya. Hal ini menunjukkan bahwa konsep diri siswa dalam mengerjakan tugas di sekolah kurang optimal karena kurangnya pengetahuan tentang diri sendiri yang mencakup keyakinan, pandangan dan penilaian fisiknya, karakteristik pribainya, motivasinya, kelemahannya atau kecakapan, kegagalannya dan sebagainya.

Adapun metakognisi sebagai suatu bentuk kognisi, atau proses berpikir dua tingkat atau lebih yang melibatkan pengendalian terhadap aktivitas kognitif. Olehnya itu, metakognisi dapat dikatakan sebagai berpikir seseorang tentang berpikirnya sendiri atau kognisi seseorang tentang kognisinya sendiri. Selain itu, metakognisi melibatkan pengetahuan dan kesadaran seseorang tentang aktivitas kognitifnya sendiri atau segala sesuatu yang berhubungan dengan aktivitas kognitifnya. Dengan demikian, aktivitas kognitif seseorang seperti perencanaan, monitoring, dan mengevaluasi penyelesaian suatu tugas tertentu merupakan metakognisi secara alami. Metakognisi atau "berpikir tentang berpikir", adalah pengetahuan dan pemahaman yang kita miliki tentang proses-proses kognitif kita sendiri dan kemampuan yang kita miliki untuk mengkaji pemikiran kita dan memantau apa yang terjadi.

Salah satu faktor penting yang sangat berpengaruh dalam keberhasilan belajar khususnya dalam memecahkan masalah matematika adalah metakognisi, konsep diri dan kemandirian belajar siswa. Hasil-hasil penelitian psikologi kontemporer menunjukkan bahwa disamping adanya faktor yang berasal dari IQ, ternyata dalam memecahkan masalah matematika sangat ditentukan oleh pengetahuan metakognisi, konsep diri dan kemandirian belajar.
Selain itu berdasarkan penelitian yang dilakukan oleh Ihsan (2016) menunjukkan bahwa metakognisi berpengaruh positif dan signifikan terhadap pemecahan masalah matematika. Lalu berdasarkan penelitian yang dilakukan oleh Hidayah (2015) menunjukkan bahwa terdapat pengaruh positif dan signifikan antara konsep diri terhadap pemecahan masalah matematika. Serta berdasarkan penelitian yang dilakukan oleh Ayudhaningrum (2017) menunjukkan bahwa terdapat pengaruh positif dan signifikan antara kemandirian belajar terhadap pemecahan masalah matematika.

Berdasarkan hasil observasi di SMAN 1 Gowa yaitu pada saat pemberian materi khususnya materi matriks kemampuan siswa pada operasi hitung matriks seperti penjumlahan, pengurangan, dan perkalian matriks masih kurang sehingga ketika diberikan latihan pemecahan soal ternyata hanya sebagian siswa yang dapat mengerjakannya dengan baik, sebagian besar tidak tahu apa yang harus dikerjakan dalam hal ini biasanya berhubungan dengan metakognisi setiap siswa yang kurang. Kemudian para siswa masih merasa malas untuk mempelajari matematika menurut mereka matematika itu adalah pelajaran yang sulit untuk dimengerti/dipahami sehingga sering kali siswa kesulitan dalam mencapai hasil belajar matematika yang maksimal. Salah satu penyebabnya adalah karena mereka sering merasa tidak yakin bahwa dirinya akan mampu menyelesaikan tugas-tugas yang dibebankan kepadanya, atau dengan kata lain kurangnya keyakinan siswa tersebut terhadap kemampuan dirinya untuk menyelesaikan tugas secara berhasil. Keyakinan tersebut biasa disebut dengan konsep diri. Pada hal telah diketahui bahwa konsep diri sangatlah berpengaruh pada hasil pemecahan masalah matematika siawa. Oleh karena itu kurangnya konsep diri siswa dalam mengerjakan tugas yang diberikan mereka lebih cenderung suka untuk menyontek dibandingkan mengerjakan tugasnya sendiri. Ini membuktikan bahwa kemandirian belajar siswa masih kurang pada hal disekolah siswa dituntut untuk bisa mandiri dalam mengerjakan tugas yang diberikan.

Selain itu hasil wawancara dengan salah satu guru mata pelajaran matematika juga 
mengatakan hasil pemecahan masalah matematika siswa juga masih rendah karena masih banyak siswa yang belum mencapai ketuntasan yang diberikan oleh guru yaitu 75 . Hal ini pelajaran yang dapat diserap oleh siswa masih kurang tentu banyak faktor yang menyebabkan ketidaktuntasan nilai mata pelajaran matematika. Dari observasi yang dilakukan dapat dilihat dari beberapa faktor yang dapat menyebabkan hasil pemecahan masalah siswa yang kurang seperti pengetahuan metakognisi yang kurang kondusif, konsep diri yang kurang serta kesadaran akan kemandirian belajar juga kurang.Tujuan dari penelitian ini adalah untuk mengetahui pengaruh metakognisi, konsep diri dan kemandirian belajar terhadap pemecahan masalah matematika siswa kelas XI IPA SMAN 1 Gowa.

\section{TINJAUAN PUSTAKA}

\section{Metakognisi}

Menurut Costa (Budiman 2014) metakognisi terdiri dari imbuhan "meta" dan "kognisi". Meta merupakan awalan untuk kognisi yang artinya "sesudah" kognisi. Penambahan awalan "meta" pada kognisi untuk merefleksikan ide bahwa metakognisi diartikan sebagai kognisi tentang kognisi, pengetahuan tentang pengetahuan atau berpikir tentang berpikir. Metakognisi kemampuan berpikir di mana yang menjadi objek berpikirnya yaitu pengetahuan dan pemahaman yang dimiliki tentang proses-proses kognitif sendiri dan kemampuan yang dimiliki untuk mengkaji pemikiran dan memantau apa yang terjadi. Selain itu, metakognisi melibatkan pengetahuan dan kesadaran seseorang tentang aktivitas kognitifnya sendiri atau segala sesuatu yang berhubungan dengan aktivitas kognitifnya. Tujuan penting mengajarkan siswa cara berfikir adalah meningkatkan kesadaran mereka akan pemikiran mereka sendiri dan mengembangkan kemampuan metakognisi dan kemampuan memantau dan mengatur pembelajaran mereka sendiri.

\section{Konsep Diri}

Calhaoum dan Acocella (Ghufron dan Risnawati Rini, 2012) mendefinisikan konsep diri sebagai suatu pemahaman mengenai diri atau ide tentang diri sendiri. Istilah konsep diri mengacu pada evaluasi bidang tertentu dari diri sendiri. Sementara itu Atwater (Puspitasari, 2014) menyebutkan bahwa konsep diri adalah keseluruhan gambaran diri yang meliputi persepsi seseorang tentang diri, perasaan, keyakinan dan nilai-nilai yang berhubungan dengan dirinya. Selanjutnya Atwater mengidentifikasi konsep diri atas tiga bentuk. Pertama, body image ( kesadaran tentang tubuhnya) yaitu bagaimana seseorang melihat dirinya sendiri. Kedua, ideal self yaitu bagaimana cita-cita dan harapan-harapan seseorang mengenai dirinya. Ketiga, social self yaitu bagaimana orang melihat dirinya.

\section{Kemandirian Belajar}

Menurut Moore dalam (Nurhayati,2012) pembelajaran yang memiliki kemandirian dalam menentukan tujuan dan cara belajar menjadi ciri penting yang membedakan dengan pembelajaran yang tidak mandiri karna perbedaan ini pulalah hasil pemecahan masalah yang diperoleh dapat dievakuasi sendiri untuk bahan pembelajaran lebih lanjut. Sedangkan Mudjiman (2007) menyatakan: "belajar mandiri adalah kegiatan belajar aktif, yang didorong oleh niat atau motif untuk menguasai sesuatu kompetensi guna mengatasi sesuatu masalah, dan dibangun dengan bekal pengetahuan atau kompetensi yang telah dimiliki”. Menurut Umar dan La Sulo (2015) kemandirian belajar diartikan sebagai aktivitas belajar yang berlangsungnya lebih didorong oleh kemauan sendiri, pilihan sendiri, dan disertai rasa tanggung jawab dari diri pembelajar.

\section{Pemecahan Masalah Matematika}

Menurut Rusaffendi (Saputra, 2012) belajar pemecahan masalah matematika pada dasarnya adalah belajar menggunakan metodemetode ilmiah atau berfikir secara sistematis, logis, teratur, dan teliti. Tujuannya adalah untuk memperoleh kemampuan dan kecakapan kognitif untuk memecahkan masalah secara rasional, lugas, dan tuntas. Untuk itu, kemampuan siswa dalam menguasai konsep-konsep, prinsipprinsip, dan generalisasi serta insting (titikan awal) sangat diperlukan. 


\section{METODOLOGI}

Jenis penelitian ini adalah ex-post facto yang bersifat kausalitas. Penelitian ini dilakukan di SMAN 1 Gowa. Populasi dalam penelitian ini adalah seluruh siswa kelas XI IPA SMAN 1 Gowa. Teknik pengambilan sampel dalam penelitian ini adalah cluster random sampling dengan memilih dua kelas secara acak dari 6 kelas yang ada untuk menentukan kelas penelitian. Kelas dalam penelitian ini adalah XI IPA 5 dan XI IPA 6 yang terdiri dari 65 siswa. Adapun teknik analisis data yang digunakan dalam penelitian ini adalah angket dan tes.

\section{Prosedur Analisis}

1. Teknik analisis statistik deskriptif

2. Teknik analisis statistik inferensial

\section{PEMBAHASAN}

\section{Deskripsi Data}

Berikut ini hasil analisis deskriptif menunjukkan deskripsi tentang karakteristik distribusi nilai dari masing-masing kelas penelitian.

Tabel 1. Statistik Deskriptif Metakognisi

\begin{tabular}{lr}
\hline \multicolumn{1}{c}{ Statistik } & Nilai Statis \\
\hline Mean & 69,26 \\
Median & 70,00 \\
Modus & 62,00 \\
Standar & 7,68 \\
Deviasi & 59,10 \\
Varians & 54,00 \\
Minimum & 85,00 \\
Maksimum & 0,11 \\
Skewness & $-0,58$ \\
Kurtosis & \multicolumn{2}{c}{} \\
\hline
\end{tabular}

Tabel 2. Statistik Deskriptif Konsep Diri

\begin{tabular}{cc}
\hline Statistik & Nilai Statistik \\
\hline Mean & 68,51 \\
\hline
\end{tabular}

\begin{tabular}{lr}
\hline Median & 68,00 \\
Modus & 68,00 \\
Standar Deviasi & 6,93 \\
Variansi & \multicolumn{2}{c}{49,97} \\
\multicolumn{1}{c}{ Minimum } & 56,00 \\
Maksimum & 82,00 \\
Skewness & 0,18 \\
\multicolumn{1}{c}{ Kurtosis } & $-0,86$ \\
\hline
\end{tabular}

Tabel 3. Statistik Deskriptif Kemandirian Belajar

\begin{tabular}{lc}
\hline \multicolumn{1}{c}{ Statistik } & Nilai Statistik \\
\hline Mean & 67,83 \\
Median & 68,00 \\
Modus & 72,00 \\
Standar Deviasi & 7,15 \\
Variansi & 51,17 \\
Minimum & 53,00 \\
Maksimum & 83,00 \\
Skewness & $-0,06$ \\
Kurtosis & 0,52 \\
\hline
\end{tabular}

Tabel 4. Statistik Deskriptif Pemecahan Masalah Matematika

\begin{tabular}{lc}
\hline \multicolumn{1}{c}{ Statistik } & Nilai Statistik \\
\hline Mean & 75,35 \\
Median & 80,00 \\
Modus & 84,00 \\
Standar Deviasi & 15,95 \\
Variansi & 254,63 \\
Minimum & 16,00 \\
Maksimum & 92,00 \\
Skewness & $-2,02$ \\
Kurtosis & 4,42 \\
\hline
\end{tabular}




\section{Uji prasyarat}

Tabel 5. Tabel Distribusi Uji Normalitas Menggunakan Kolmogrov Smirnov One-sample Kolmogrov- Smirnov Test

\begin{tabular}{lcccc}
\hline & X1 & X2 & X3 & Y \\
\hline $\begin{array}{l}\text { Asymp. Sig. } \\
\text { (2-tailed) }\end{array}$ & 200 & 200 & 200 & 127 \\
\hline
\end{tabular}

Berdasarkan tabel 5 maka dapat disimpulkan bahwa data dari keempat variabel penelitian yaitu metakognisi, konsep diri, kemandirian belajar dan pemecahan masalah matematika menunjukkan semua sampel lebih dari 0,05 sehingga $\mathrm{H}_{1}$ diterima. Dengan demikian data dari semua sampel penelitian berditribusi normal.

Tabel 6. Hasil Uji Multikolinearitas

\begin{tabular}{ccc}
\hline \multicolumn{1}{c}{ Variabel } & Tolerance & VIF \\
\hline Metakognisi & 0,175 & 5.718 \\
\hline Konsep Diri & 0,173 & 5.783 \\
\hline $\begin{array}{l}\text { Kemandirian } \\
\text { Belajar }\end{array}$ & 0,947 & 1.057 \\
\hline
\end{tabular}

Berdasarkan tabel 6 nilai VIF dari ketiga variabel $<10$ sehingga dapat disimpulkan bahwa pada ketiga variabel bebas tidak terjadi masalah multikolinearitas.

Tabel 7. Uji Linearitas

\begin{tabular}{cccc}
\hline Korelasi & F & Sig. & Keterangan \\
\hline $\mathrm{X} 1, \mathrm{Y}$ & 0,789 & 0,728 & Linear \\
\hline $\mathrm{X} 2, \mathrm{Y}$ & 0,984 & 0,504 & Linear \\
\hline $\mathrm{X} 3, \mathrm{Y}$ & 0,965 & 0,516 & Linear \\
\hline
\end{tabular}

Berdasarkan tabel 7 maka dapat disimpulkan bahwa data dari ketiga model garis regresi yang diuji menunjukkan nilai sig. $<0,005$ sehingga $\mathrm{H}_{1}$ diterima. Dengan kata lain semua model regresi yang diuji berpola linear.

\section{Uji hipotesis}

Hipotesis 1:

Tabel 8. Koefisien Uji Regresi linear $X_{1}$ terhadap Y

\begin{tabular}{lrrr}
\hline Model & \multicolumn{2}{c}{$\begin{array}{c}\text { Unstandardized } \\
\text { Coefficients }\end{array}$} & \multirow{2}{*}{ Sig } \\
\cline { 2 - 3 } & $\mathrm{B}$ & \multicolumn{2}{c}{ Error } \\
\hline (Constant) & -.615 & 4.133 & 0,882 \\
Metakognisi & 1.011 & 0,061 & 0,000 \\
\hline
\end{tabular}

Berdasarkan output analisis regresi sederhana pada table 7 coefficients, dapat dilihat nilai $\beta_{1}=1,011$ dengan nilai sig $=0,000$ pada taraf signifikan $\alpha=0,05$. Karena nilai sig lebih kecil dari nilai $\alpha$ yaitu $0,000<0,05$, maka hal tersebut berarti $\mathrm{H}_{0}$ ditolak dan $\mathrm{H}_{1}$ diterima, sehingga dapat disimpulkan bahwa terdapat pengaruh signifikan metakognisi terhadap pemecahan masalah matematika siswa kelas XI IPA SMAN 1 Gowa sebesar 81,2\%. Dari data tersebut dapat disusun persamaan regresinya sebagai berikut: $Y=-0,615+1,011 X_{1}$.

Hipotesis 2:

Tabel 9. Koefisien Uji Regresi linear $X_{2}$ terhadap Y

\begin{tabular}{lccc}
\hline Model & \multicolumn{2}{c}{ Unstandardized } & \multirow{2}{*}{ Sig } \\
\cline { 2 - 3 } & Coefficients & \\
& B & Std. \\
& Error \\
\hline (Constant) & -6.250 & 3.167 & 0,053 \\
Konsep Diri & 1.090 & 0.047 & 0,000 \\
\hline
\end{tabular}

Berdasarkan output analisis regresi sederhana pada tabel 9 coefficients, dapat dilihat nilai $\beta_{2}=1.090$ dengan nilai sig $=0,000$ pada taraf signifikan $\alpha=0,05$. Karena nilai sig lebih kecil dari nilai $\alpha$ yaitu $0,000<0,05$, maka hal tersebut berarti $\mathrm{H}_{0}$ ditolak dan $\mathrm{H}_{1}$ diterima, sehingga dapat disimpulkan bahwa terdapat pengaruh signifikan konsep diri terhadap pemecahan masalah matematika siswa kelas XI IPA SMAN 1 Gowa sebesar 89,6\%. Dari data tersebut dapat disusun persamaan regresinya sebagai berikut: $Y=-6,250+1,090 X_{2}$.

Hipotesis 3: 
Tabel 10. Koefisien Uji Regresi linear $X_{3}$ terhadap Y

\begin{tabular}{lccc}
\hline Model & \multicolumn{2}{c}{ Unstandardized } & \multirow{2}{*}{ sig } \\
& \multicolumn{2}{c}{ Coefficients } & \\
\cline { 2 - 3 } & $\mathrm{B}$ & $\begin{array}{c}\text { Std. } \\
\text { Error }\end{array}$ \\
\hline (Constant) & 5.677 & 4.562 & 0,218 \\
$\begin{array}{l}\text { Kemandirian } \\
\text { belajar }\end{array}$ & 0.905 & 0.067 & 0,000 \\
\hline
\end{tabular}

Berdasarkan output analisis regresi ganda pada table 10 coefficients, dapat dilihat nilai $\beta_{3}=$ 0,905 dengan nilai sig $=0,000$ pada taraf signifikan $a=0,05$ yang berarti sig $<0,05$. Hal tersebut berarti $\mathrm{H}_{0}$ ditolak dan $\mathrm{H}_{1}$ diterima, sehingga dapat disimpulkan bahwa terdapat pengaruh signifikan kemandirian belajar terhadap pemecahan masalah matematika siswa kelas XI IPA SMAN 1 Gowa sebesar 74,4\%. Dari data tersebut dapat disusun persamaan regresinya sebagai berikut: $Y=5,677+$ $0,905 X_{3}$.

Hipotesis 3:

Tabel 11. Koefisien Uji Regresi linear $\mathrm{X}_{1}, \mathrm{X}_{2}, \mathrm{X}_{3}$ terhadap Y

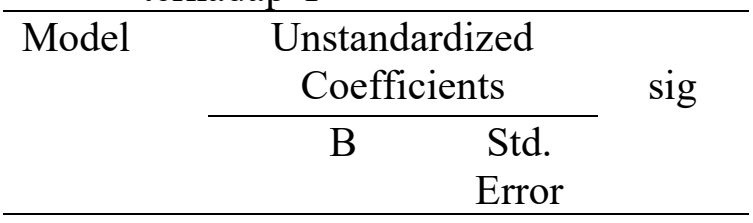

Berdasarkan hasil analisis statistik deskriptif dan statistik inferensial, maka dapat disimpulkan sebagai berikut :

1. Gambaran tentang metakognisi siswa kelas XI IPA SMAN 1 Gowa berada pada kategori sangat tinggi dengan persentase $64,62 \%$. Begitu juga dengan konsep diri pada kategori sangat tinggi dengan persentase $69,23 \%$ dan kemandirian belajar pada kategori sangat tinggi dengan persentase $61,54 \%$. Sedangkan pada kemampuan pemecahan masalah matematika berada pada kategori baik dengan persentase $35,38 \%$.

2. Terdapat pengaruh positif dan signifikan metakognisi terhadap pemecahan masalah matematika siswa kelas XI IPA SMAN 1 Gowa sebesar $81,2 \%$.

3. Terdapat pengaruh positif dan signifikan konsep diri terhadap pemecahan masalah

\begin{tabular}{lccc}
\hline (Constant) & 10.160 & 3.297 & 0.003 \\
metakognisi & 0.226 & 0.092 & 0.017 \\
Konsep diri & 0.871 & 0.095 & 0.000 \\
Kemandirian & 0.050 & 0.025 & 0.048 \\
belajar & & & \\
\hline
\end{tabular}

Berdasarkan output analisis regresi ganda pada table 11 coefficients, dapat dilihat nilai $\beta_{1}=$ 0,226 dengan nilai $\mathrm{P}$ Value $=0,017$ pada taraf signifikan $a=0,05$ yang berarti $\operatorname{sig}<0,05$, $\beta_{2}=0,871$ dengan nilai sig $=0,000$ pada taraf signifikan $a=0,05$, yang berarti $\operatorname{sig}<0,05$, $\beta_{3}=0,050$ dengan nilai sig $=0,048$ pada taraf signifikan $a=0,05$, yang berarti sig $<0,05$. Hal tersebut berarti $\mathrm{H}_{0}$ ditolak dan $\mathrm{H}_{1}$ diterima.

Dari tabel ANOVA diperoleh nilai $F_{\text {hitung }}$ $=247,931$. Untuk $F_{\text {tabel }}$ dengan taraf signifikan sebesar 5\%, diperoleh $F_{\text {tabel }}=2,75$. Dan diperoleh nilai sig $0,000<0,05$, maka dapat disimpulkan bahwa $\mathrm{H}_{0}$ ditolak. Sehingga terdapat pengaruh signifikan metakognisi, konsep diri dan kemandirian belajar terhadap pemecahan masalah matematika sebesar 92,4\%. Adapun persamaan regresi ganda yang diperoleh sebagai berikut:

$$
Y=10.160+0,226 X_{1}+0,871 X_{2}+0,050 X_{3}
$$

\section{KESIMPULAN}

matematika siswa kelas XI IPA SMAN 1 Gowa sebesar 89,6\%.

4. Terdapat pengaruh positif dan signifikan kemandirian belajar terhadap pemecahan masalah matematika siswa kelas XI IPA SMAN 1 Gowa sebesar 74,4\%.

5. Terdapat pengaruh positif dan signifikan metakognisi, motivasi belajar konsep diri dan kemandirian belajar secara bersama-sama terhadap pemecahan masalah matematika siswa sebesar $92,4 \%$.

\section{DAFTAR PUSTAKA}

[1] Ayudhaningrum, Yuliana. 2017. Pengaruh kedisiplinan dan kemandirian belajar terhadap kemampuan pemecahan masalah matematika. Jurnal Pendidikan Matematika Indonesia. Vol. 10, No. 1, Hal 48 
[2] Budiman. 2014 Strategi Membangun Metakognisi Siswa SMA dalam Pemecahan Masalah Matematika. Jurnal Daya Matematis Matematika. Vol. 3, No. 1, Hal 20

[3] Ghufron, Nur dan Risnawati Rini. 2012. Pengaruh konsep diri, sikap siswa pada matematika, dan kecemasan siswa terhadap hasil belajar matematika: Cakrawala Pendidikan.

[4] Hidayah, Muslihatul. 2015. Pengaruh konsep diri dan kecemasan belajar terhadap kemampuan menyelesaikan masalah matematika pada siswa Madrasah Aliyah Negeri di Jakarta Barat. Jurnal Buletin Psikologi. Vol. 21, No. 1, Hal 26-27

[5] Nurhayati. 2012. Pengaruh Motivasi Berprestasi dan Kemandirian Belajar Terhadap Prestasi Belajar Siswa Kelas XI IPS SMA Negeri 2 Bantul Tahun Ajaran 2009/2010. Jurnal Ilmiah Pendidikan Matematika. Vol. 6, No. 2. Hal 80.
[6] Ihsan, Muhammad. 2016. Pengaruh Metakognisi dan Motivasi terhadap Kemampuan Pemecahan Masalah Matematika melalui Kreativitas siswa kelas VIII SMP Negeri di kecamatan Kindang Kabupaten Bulukumba. Jurnal Ilmiah Pendidikan Matematika. Vol. 5, No. 1, Hal 85

[7] Ningsih, Rita \& Arfatin Nurrahmah . 2016. Pengaruh Metakognisi Dan Perhatian Orang Tua Terhadap Prestasi Belajar Matematika. Jakarta: Jurnal Formatif 6(1): 73-84

[8] Saputra. 2012. Pemecahan Masalah dalam Pembelajaran Matematika SMA. Jurnal digital library Universitas Islam Negeri Sunan Kalijaga Yogyakata 